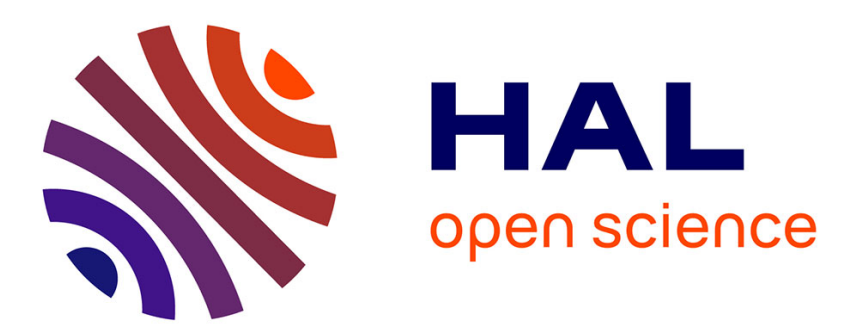

\title{
Adventitious root formation in tree species: involvement of transcription factors
}

Valérie Legué, Adeline Rigal, Rishikesh P. Bhalerao

\section{To cite this version:}

Valérie Legué, Adeline Rigal, Rishikesh P. Bhalerao. Adventitious root formation in tree species: involvement of transcription factors. Physiologia Plantarum, 2014, 151 (2), pp.192-198. 10.1111/ppl.12197 . hal-00997794v2

\section{HAL Id: hal-00997794 \\ https://hal.science/hal-00997794v2}

Submitted on 1 Apr 2015

HAL is a multi-disciplinary open access archive for the deposit and dissemination of scientific research documents, whether they are published or not. The documents may come from teaching and research institutions in France or abroad, or from public or private research centers.
L'archive ouverte pluridisciplinaire HAL, est destinée au dépôt et à la diffusion de documents scientifiques de niveau recherche, publiés ou non, émanant des établissements d'enseignement et de recherche français ou étrangers, des laboratoires publics ou privés. 
MINIREVIEW

\title{
Adventitious root formation in tree species: involvement of transcription factors
}

\author{
Valérie Leguéa ${ }^{a, b, c, *}$, Adeline Rigald $^{d}$ and Rishikesh P. Bhalerao ${ }^{d, *}$ \\ aINRA and Université de Lorraine, UMR Interactions Arbres/Micro-organismes 1136, F-54280 Champenoux, France \\ ${ }^{b}$ Clermont Université, Université Blaise-Pascal, UMR 547 PIAF, BP 10448, F-63000 Clermont-Ferrand, France \\ CINRA, UMR 547 PIAF, F-63100 Clermont-Ferrand, France \\ ¿Umeå Plant Science Center, Department of Forest Genetics and Plant Physiology, The Swedish University of Agricultural Sciences, SE-901 83 Umeå, \\ Sweden
}

\author{
Correspondence \\ *Corresponding authors, \\ e-mail: Valerie.LEGUE@univ-bpclermont.fr; \\ rishi.bhalerao@slu.se \\ Received 28 October 2013; \\ revised 27 February 2014
}

doi:10.1111/ppl.12197

\begin{abstract}
Adventitious rooting is an essential step in the vegetative propagation of economically important horticultural and woody species. Populus has emerged as an experimental model for studying processes that are important in tree growth and development. It is highly useful for molecular genetic analysis of adventitious roots in trees. In this short review, we will highlight the recent progress made in the identification of transcription factors involved in the control of adventitious rooting in woody species. Their regulation will be discussed.
\end{abstract}

\section{Introduction}

In contrast to lateral roots (LRs), which are formed on primary roots, adventitious roots (ARs) are formed from above-ground organs such as hypocotyls, stems and leaves. A further major distinction between LRs and ARs is that unlike LRs, which originate from pericycle cells, ARs originate from cambial or other meristematic cells. Thus the study of ARs provides an experimental system to investigate mechanisms of secondary root formation distinct from the well-characterized LR system.

The ability to rapidly form numerous ARs offers a selective advantage to plant species that propagate vegetatively, so playing a central role in clonal propagation. Clonal propagation is of particular relevance to forestry and horticulture, since genetic improvement in long-lived species with long generation cycles is often limiting. Despite this importance, our knowledge of adventitious rooting is limited in trees. To date, only a few genes have been identified that regulate the AR in woody species. This review charts the most recent progress in understanding AR control in woody plants.

\section{Populus as a tree model for deciphering AR molecular mechanisms}

Understanding AR formation in trees is important when devising strategies for large-scale vegetative propagation in these economically important plants. However, in most tree species, the ability to form ARs declines with age. The molecular basis of this decline is not known. Physiological and anatomical studies on AR formation have long been published, but the factors underlying ARs in trees remain largely unknown, for lack of a good model. In recent years Populus has emerged as an experimental model for studying processes that are important in tree growth and development, and is highly useful for molecular genetic analysis of ARs in trees. The genus Populus is a typical woody species propagated by direct planting of stem cuttings in the field (Bonduelle 1989, Dickmann 2006). Represented by approximately 30 species widely distributed in the Northern Hemisphere (Eckenwalder 1996), poplars are fast-growing plants showing high adaptability to marginal soils, making them plants of choice for timber,

Abbreviations - ACC, aminocyclopropane-1-carboxylate; AR, adventitious root; ARF, auxin response factor; LR, lateral root; RNAi, RNA interference; TF, transcription factor. 
pulp and bioenergy-related applications. For poplars, clonal propagation is the only way to deploy genetically improved varieties. Therefore identification of the molecular mechanisms underlying adventitious rooting should not only provide insight into the control of AR formation in trees, but also open up possibilities for improving this trait in economically important plants including Populus, for which clonal propagation is a requirement. There have recently been important developments in the molecular genetics and genomics of Populus, resulting in a consensus among the scientific community for employing poplar as a woody perennial plant (Brunner et al. 2004, review Busov et al. 2009, Yang et al. 2009). First, genetic and genomic resources have increased in the last 10 years. The sequencing and annotation of the black cottonwood genome (Tuskan et al. 2006) are up-dated regularly and are implanted in the Phytozome web site (http://www.phytozome.net/poplar.php). Whole-genome oligo-array data generated create an opportunity to identify differential regulation of gene expression relative to some developmental events including LR and AR formation (Quesada et al. 2008, Felten et al. 2009, Ramírez-Carvajal et al. 2009, Gou et al. 2010, Rigal et al. 2012). Second, efficient transformation systems for many Populus species including the hybrid Populus tremula $\times$ Populus alba clone INRA 717-1B4 and P. tremula $\times$ P. tremuloïdes have been reported by several laboratories (Leple et al. 1992, Han et al. 2000), and allow the construction and the regeneration of a large number of transgenic plants including RNA interference (RNAi) lines and activation-tagged mutants (Busov et al. 2005, 2009). For example, activation-tagged mutants have been successively used for identifying genes involved in $L R$ and $A R$ formation (Busov et al. 2010, Wang et al. 2011, Trupiano et al. 2013). In parallel, the technique of enhancer and gene trap mutagenesis has been applied to Populus to identify gene expression patterns correlating with different stages of AR formation (Ramírez-Carvajal et al. 2009, Rigal et al. 2012). Third, the easy vegetative propagation of many genotypes of Populus plays an important role in the successful production of elite clones.

\section{Cellular events during AR formation}

The processes involved in AR formation are complex, and occur in four stages (Fig. 1): (1) activation, where the cells become competent to respond to signal factors, (2) induction, when cell cycle re-activation leads progressively to the formation of primordium, and the cell division is visible, (3) activation of root primordium and progressive formation of new tissues and (4) outgrowth, where root primordium elongates and vascular connections are established. These rooting phases are distinguished from a broad variety of genera including apple microcuttings, from Eucalyptus, Pinus and from Populus cuttings (De Klerk et al. 1997, 1999, Fett-Neto et al. 2001). In woody plants including P. trichocarpa, the first mitotic divisions, leading to root primordia formation, take place more frequently from the cambium and vascular tissues from ray cells adjacent to the vascular cambium (De Klerk et al. 1997, Rigal et al. 2012). In some Populus species, the formation of a callus is observed prior to differentiation of root primordia at the base of the cuttings (Lovel and White 1986). Although in many respects the stages in AR formation resemble what occurs during LR formation, the target tissues are different for LRs and ARs, with LRs originating from pericycle cells, whereas ARs seem to derive from cambial meristem tissues for trees species. Also, unlike LRs, in which one of the first stages is asymmetric cell division in the pericycle, asymmetric division in AR formation has not been reported to date.

\section{Transcription factor families: master regulators of adventitious rooting}

Understanding the molecular basis of LR formation has been aided by transcriptomic approaches. These have identified (1) gene expression programs associated with distinct stages of LR formation and (2) key players, many of which are transcription factors (TFs) in the model plant Arabidopsis. The success of these approaches has prompted similar analysis of ARs in trees. The transcriptomic analysis performed in poplar at different stages of AR formation has revealed significant transcriptome remodeling during the AR formation including Pinus taeda (Brinker et al. 2004), Populus sp. (Ramírez-Carvajal et al. 2009, Rigal et al. 2012) and Eucalyptus grandis (Abu-Abied et al. 2012). Among transcripts, genes encoding putative TFs belonging to 35 TF families have significant expression changes at the successive stages of poplar AR formation (Rigal et al. 2012). The function of these genes is not yet known. Induction of increased mRNA levels of genes homologous to $S C R$ (SCR-like or $S C L$ ) in rooting-competent cuttings of Pinus radiata and Castanea sativa species was observed within the first $24 \mathrm{~h}$ of the root induction process, a time when cell reorganization takes place, and preceding the establishment of AR primordium (Sanchez et al. 2007). SCARECROW (SCR) is a member of the GRAS family of TFs, acting in the control of cell division, differentiation and cell homeostasis (Heidstra et al. 2004, Wildwater et al. 2005) during the establishment of Arabidopsis thaliana root meristem. Interestingly, SCR is downstream-regulated by a 


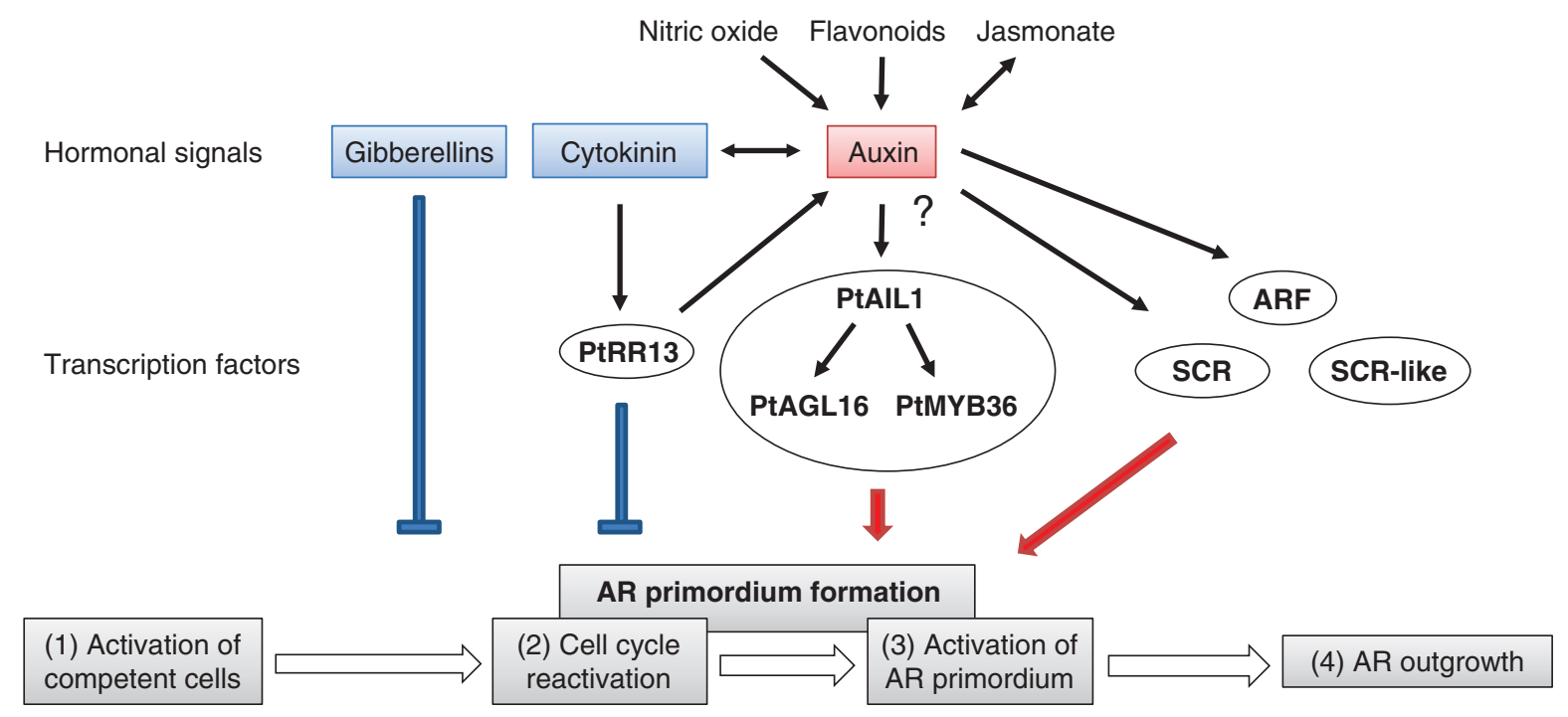

Fig. 1. Possible hormonal regulation of TF during the successive stages of the adventitious rooting in tree species. The AR formation can be seen as a four-stage process starting with the activation of cells in response to signal factors (1). This step is followed by the cell cycle re-activation (2), which leads progressively to the AR primordium formation. The activation of root primordium (3) allows the formation of new tissues and (4) AR outgrowth. Auxin promotes the activation of competent cells and then the formation of AR primordium. NO may participate in this process through the auxin signaling pathways. In parallel, the auxin transport may be influenced after the cutting and may be regulated by the accumulation of jasmonates or flavonoids. In contrast, cytokinin and GA have an inhibitory effect on adventitious rooting. Some transcription factors have been identified as regulators of AR formation in trees including PtRR13, which is regulated by a cytokinin/auxin balance, and SCR is regulated by auxin. PtAIL1, a member of AP2/ERF family plays a major role in the formation of AR primordium, and could take part in the PtAGL16- and PtMYB36-dependent regulatory network.

plant homolog of the tumor suppressor Retinoblastoma $(\mathrm{pRb})$, the RETINOBLASTOMA-RELATED $(R B R)$ gene is considered a key cell cycle regulator (Borghi et al. 2010). In root-forming shoots, CsSCL1, SCL in C. sativa, mRNA was specifically located in the cambial zone and derivative cells, which are rooting-competent cells, whereas in rooting-incompetent shoots the hybridization signal was diffuse and evenly distributed throughout the phloem and parenchyma (Vielba et al. 2011). These studies highlight an important role for SCR in meristem determination and maintenance during the formation of AR primordium.

An up-expression of LR primordium (Irp1), which is an SRS-type TF, has been detected. This gene is known to be involved in lateral and AR primordium formation in Arabidopsis (Smith and Fedoroff 1995). Transcriptomic data obtained in $P$. trichocarpa adventitious rooting (Rigal et al. 2012) reveal a modulation of some members of the auxin response factor (ARF) family. ARF proteins are TFs that regulate the expression of auxin response genes. Genetic analysis in Arabidopsis clearly shows the importance of this family in the adventitious process (Gutierrez et al. 2009).

One of the best characterized TFs with a role in AR formation in trees is the AP2/ERF protein family comprising TFs unique to plants (Reichman and Meyerowitz 1998), which all contain the conserved AP2 DNA-binding domain (Jofuku et al. 1994). This super-family consists of 210 members in poplar and regulates two major processes in plants including response to stress and control of development. AINTEGUMENTA-like subgroup members, such as PLETHORA (AtPLT), BABY BOOM (AtBBM), AINTEGUMENTA (AtANT) and AINTEGUMENTA-like (AtAIL) play a major role in the establishment and maintenance of meristems (Krizek et al. 2000, Mizukami and Fischer 2000, Nole-Wilson et al. 2005, Imin et al. 2007, review, Horstman et al. 2014). AINTEGUMENTA (AtANT) plays a role in the regulation of shoot development during organ primordium initiation and growth (Elliott etal. 1996), and in maintaining meristematic competence of cells during shoot organogenesis (Mizukami and Fischer 2000). Interestingly, some members of this family show a regulation of their expression, suggesting a key role for this subgroup in the control of adventitious rooting in poplars (Rigal et al. 2012). The organization of the poplar root primordium is accompanied by the up-regulation of PtAIL1, PtAIL9, PtPLT1.2 and Pt $B B M 2$, while the differentiation of the root primordium showed expression regulation of PtAIL1, PtAIL5, PtAIL9, PtPLT1.1, PtPLT1.2 and PtBBM2. In contrast to the others, the expression of PtAIL1 transcript levels shows a very specific expression regulation during AR primordium activation and formation. Moreover, transgenic poplar lines over-expressing PtAlL1 exhibited an increased 
number of ARs, while RNAi downregulation of PtAIL1 transcript showed a reduced number of ARs. AINTEGUMENTA LIKE 1 (PtAIL1), which has been noted to be a Populus homolog of the Arabidopsis gene AINTEGUMENTA (ANT) (Karlberg et al. 2011), is expressed in the cambial zone within cells that undergo intensive cell proliferation (Schrader et al. 2004). In addition, PtAIL1 has been shown to bind to the D-type cyclin promoter in hybrid aspen trees and Arabidopsis (Karlberg et al. 2011). Taken together, these data suggest that PtAlL1 could be involved in cell proliferation occurring during the AR primordium formation. The comparison of global gene expression profiles between the wild type, PtAlL1 overexpressors and RNAi suppression lines indicates a co-regulation of AGAMOUS-Like16 (PtAGL16), PtMYB36 and PtAIL1. This suggests that PtAIL1, PtAGL16 and PtMYB36 could be part of a regulatory network that controls AR formation in poplars (Rigal et al. 2012). Additionally, a member of the AP2/ERF family, called PtaERF003, has a positive effect on both adventitious and LR proliferation in poplar (Trupiano et al. 2013).

\section{AR formation integrates multiple hormonal pathways}

Most research on AR formation has been centered on the role of phytohormones, mainly auxins (reviews: Geiss et al. 2009, Da Costa et al. 2013). Classically, treatments of cuttings with synthetic auxins have been used for many years to induce and accelerate rooting in difficult-to-root species (Kevers et al. 1997). In poplar cuttings, anti-auxin application at AR phases caused significant inhibition of AR (Bellamine et al. 1998). In P. taeda stem cuttings, the inability to root in mature cuttings was due to the lack of cell capacity to organize root meristems in the presence of auxin (Greenwood et al. 2001). More recently, Negishi et al. (2011) compared E. globulus easy- and difficult-to-root lines, and showed that the indole-3-acetic acid (IAA) level of the easy-rooting line was twice that of the difficult-rooting line, confirming the importance of auxin in AR formation ability.

Examining the loss of rooting capability following the transition from the juvenile to the mature phase in $E$. grandis (Abu-Abied et al. 2012), the authors observed a higher transient burst of nitric oxide (NO) in juvenile cuttings than in mature ones upon excision. A gene encoding for nitrate reductase (NIA), which is involved in $\mathrm{NO}$ production, was among the genes upregulated in juvenile cuttings (Abu-Abied et al. 2012). Thus NO may influence auxin signaling, as already observed in Arabidopsis (Mittler et al. 2011).
Overall changes in phytohormone balance during AR formation have been reported in several studies. In a recent review, the authors (Da Costa et al. 2013) propose an elegant view of phytohormonal control of AR formation and possible hormonal interactions during distinct phases of the adventitious rooting process. The importance of jasmonate-transport auxin interaction has been highlighted during the Arabidopsis root development (Sun et al. 2011, Raya-González et al. 2012). Interestingly, it encompasses the first hours after cutting removal; the observed local increase in jasmonate was associated with the phenolic compounds and auxin at the Eucalyptus cutting base (Schwambach et al. 2008). Phenolics are also important in modulating peroxidase activity, and may thus prevent auxin degradation at cutting bases (De Klerk et al. 1999, 2011). Flavonoids, a major class of phenolic compounds, can influence auxin transport (Peer and Murphy 2007, Buer et al. 2010). Auxin and cytokinins appear to play antagonistic roles in AR formation. The quantification of these two hormones in the basal part of cuttings from diverse woody species including Populus and Malus revealed an opposite pattern in auxin and cytokinin concentrations during the first steps of AR formation. In addition, exogenous application of cytokinin to cutting during the induction phase strongly inhibited Malus root formation (De Klerk et al. 1999). Ramírez-Carvajal et al. revealed an induction of transcript abundance of members of aminocyclopropane-1-carboxylate (ACC) synthase, and ACC oxidase, key enzymes involved in cytokinin synthesis (Ramírez-Carvajal et al. 2009). A TF, the cytokinin type-B response regulator PtRR13, which acts as a positive regulator in the cytokinin signaling pathway, has been shown to repress AR formation in intact plants, and reduced cytokinin signaling after shoot excision. Cytokinin may interact with ethylene and auxin pathways (Ramírez-Carvajal et al. 2009). Like cytokinins, gibberellins have been considered as inhibitors of AR formation in poplar (Busov et al. 2006).

\section{Hormonal pathways: possible regulators of TFs}

The root meristem formation and maintenance are controlled by the hormonal balance, where cytokinins and auxins act antagonistically (Dello loio et al. 2007, Moubayidin et al. 2009). Some auxin-responsive TFs have been shown to play roles in the control of cell division leading to root primordia differentiation in cuttings of tree species (Sanchez et al. 2007, Solé et al. 2008, Vielba et al. 2011, Rigal et al. 2012). Induction of increased mRNA levels of genes homologous 
to SCR (SCR-like or $S C L$ ) in rooting-competent cuttings of $P$. radiata and $C$. sativa species in response to exogenous auxin was observed within the early steps of AR formation (Sanchez et al. 2007). The expression of two APETALA2/ETHYLENE RESPONSE FACTOR (AP2/ERF) TF genes has been inhibited by the expression of a cytokinin type-B response regulator (PtRR13) (Ramírez-Carvajal et al. 2009). More recently, the positive regulator PtaERF003 of AR formation in Populus was up-regulated by auxin (Trupiano et al. 2013). Thus some findings suggest how hormonal balance triggers $A R$ formation through the regulation of TFs expression. On the basis of these results, we propose a model illustrating the possible hormonal regulation of TF in the control of adventitious rooting in tree species (Fig. 1).

The further identification of target genes of the TF will offer a fuller understanding of the control of AR formation. Recently, an integrative database of the TFs from economically important tree crops including poplar called TreeTFDB (http:// treetfdb.bmep.riken.jp/index.pl) has become available for the community, and offers genetic resources for performing comparative and functional genomics of the crop TFs (Mochida et al. 2013). Use of similar databases together with resources such as POPGENIE will allow better integration of transcriptomics data with physiological and anatomical approaches used previously for analysis of AR formation in trees, and will provide a much better insight into this important process. Concomitantly, the developments of genomic and transcriptomic tools in woody species including Eucalyptus and Pinus species will offer exciting perspectives in this research area. Comparative transcriptome analysis of genotypes that differ in their competence to adventitious rooting should be explored, and will be very helpful for understanding molecular mechanisms in AR formation in trees.

Acknowledgements - The authors thank Région de Lorraine, the European Project Energy Poplar (FP7-211917), and the French space agency, the Centre National d'Etudes Spatiales (CNES) for financial support. This work was also supported by a public grant overseen by the French National Research Agency (ANR) as part of the "Investissements d'Avenir" program (reference: ANR-11-LABX-0002-01, Lab of Excellence ARBRE).

\section{References}

Abu-Abied M, Szwerdszarf D, Morde-Haev I, Levy A, Rogovoy O, Belausov E, Yaniv Y, Uliel S, Katzenellenbogen M, Riov J, Ophir R, Sadot E (2012) Microarray analysis revealed upregulation of nitrate reductase in juvenile cuttings of Eucalyptus grandis, which correlated with increased nitric oxide production and adventitious root formation. Plant J 71: 787-799

Bellamine J, Penel C, Greppin H, Gaspar T (1998)

Confirmation of the role of auxin and calcium in the late phases of adventitious root formation. Plant Growth Regul 26: 191-194

Bonduelle P (1989) Poplar silviculture in short rotation coppices. Biomass production. Informations-Foret, Afocel-Armef 2: 1-39

Borghi L, Gutzat R, Fütterer J, Laizet Y, Hennig L, Gruissem W (2010) Arabidopsis RETINOBLASTOMA-RELATED is required for stem cell maintenance, cell differentiation, and lateral organ production. Plant Cell 22: 1792-1811

Brinker M, van Zyl L, Liu W, Craig D, Sederoff RR, Clapham DH, von Arnold S (2004) Microarray analyses of gene expression during adventitious root development in Pinus contorta. Plant Physiol 135: 1526-1539

Brunner AM, Yakovlev IA, Strauss SH (2004) Validating internal controls for quantitative plant gene expression studies. BMC Plant Biol 4: 14

Buer CS, Imin N, Djordjevic MA (2010) Flavonoids: new roles for old molecules. J Integr Plant Biol 52: 98-111

Busov VB, Brunner AM, Meilan R, Filichkin S, Ganio L, Gandhi S, Strauss SH (2005) Genetic transformation: a powerful tool for dissection of adaptive traits in trees. New Phytol 167: 9-18

Busov V, Meilan R, Pearce DW, Rood SB, Ma C, Tschaplinski TJ, Strauss SH (2006) Transgenic modification of gai or rg/1 causes dwarfing and alters gibberellins, root growth, and metabolite profile in Populus. Planta 224: 288-299

Busov VB, Yordanov YS, Meilan R (2009) Discovery of genes involved in adventitious root formation using Populus as a model. In: Niemi K, Scagel C (eds) Adventitious Root Formation of Forest Trees and Horticultural Plants - From Genes to Applications. Research Signpost, Kerala, India, pp 85-104

Busov V, Yordanov YS, Gou J, Meilan R, Ma C, Regan S, Strauss $S$ (2010) Activation tagging is an effective gene tagging system in Populus. Tree Genet Genomes 7: $91-101$

Da Costa CT, de Almeida MR, Ruedell CM, Schwambach J, Maraschin FS, Fett-Neto AG (2013) When stress and development go hand in hand: main hormonal controls of adventitious rooting in cuttings. Front Plant Sci 4: 133. DOI: 10.3389/fpls.2013.00133

De Klerk GJ, Arnholdt-Schmitt B, Lieberei R, Neumann KH (1997) Regeneration of roots, shoots and embryos: physiological, biochemical and molecular aspects. Biol Plant 39: 53-56

De Klerk GJ, Van der Krieken W, De Jong JC (1999) The formation of adventitious roots: new concepts, new possibilities. In Vitro Cell Dev Biol Plant 35: 189-199

De Klerk GJ, Guan H, Huisman P, Marinova S (2011) Effects of phenolic compounds on adventitious root 
formation and oxidative decarboxylation of applied indoleacetic acid in Malus 'Jork 9'. Plant Growth Regul 63: $175-185$

Dello loio R, Linhares FS, Scacchi E, Casamitjana-Martinez E, Heidstra R, Costantino P, Sabatini S (2007) Cytokinins determine Arabidopsis root meristem size by controlling cell differentiation. Curr Biol 17: 678-682

Dickmann D (2006) Silviculture and biology of short-rotation woody crops in temperate regions: then and now. Biomass Bioenergy 30: 696-705

Eckenwalder JE (1996) Systematics and evolution of Populus. In: Stettler RF, Bradshaw HD Jr, Heilman PE, Hinckley TM (eds) Biology of Populus and its Implications for Management and Conservation. NRC Research Press, National Research Council of Canada, Ottawa, Ontario, Canada, pp 7-32

Elliott RC, Betzner AS, Huttner E, Oakes MP, Tucker WQ, Gerentes D, Perez P, Smyth DR (1996)

AINTEGUMENTA, an APETALA2-like gene of Arabidopsis with pleiotropic roles in ovule development and floral organ growth. Plant Cell 8: 155-168

Felten J, Kohler A, Morin E, Bhalerao RP, Palme K, Martin F, Ditengou FA, Legué V (2009) The ectomycorrhizal fungus Laccaria bicolor stimulates lateral root formation in Poplar and Arabidopsis through auxin transport and signaling. Plant Physiol 151: 1991-2005

Fett-Neto AG, Fett JP, Goulart LWV, Pasquali G, Termignoni RR, Ferreira AG (2001) Distinct effects of auxin and light on adventitious root development in Eucalyptus saligna and Eucalyptus globulus. Tree Physiol 21: 457-464

Geiss G, Gutierrez L, Bellini C (2009) Adventitious root formation: new insights and perspectives. In: Beeckman T (ed) Annual Plant Reviews, Vol 37: Root Development. Wiley- Blackwell, Oxford, UK

Gou J, Strauss SH, Tsai CJ, Fang K, Chen Y, Jiang X, Busov VB (2010) Gibberellins regulate lateral root formation in Populus through interactions with auxins and other hormones. Plant Cell 22: 623-639

Greenwood MS, Cui X, Xu F (2001) Response to auxin changes during maturation-related loss of adventitious rooting competence in loblolly pine (Pinus taeda) stem cuttings. Physiol Plant 111: 373-380

Gutierrez L, Bussell JD, Pacurar DI, Schwambach J, Pacurar M, Bellini C (2009) Phenotypic plasticity of adventitious rooting in Arabidopsis is controlled by complex regulation of AUXIN RESPONSE FACTOR transcripts and microRNA abundance. Plant Cell 21: 3119-3132

Han KH, Meilan R, Ma C, Strauss SH (2000) An Agrobacterium tumefaciens transformation protocol effective on a variety of cottonwood hybrids (genus Populus). Plant Cell Rep 19: 315-320

Heidstra R, Welch D, Scheres B (2004) Mosaic analyses using marked activation and deletion clones dissect Arabidopsis SCARECROW action in asymmetric cell division. Genes Dev 18: 1964-1969
Horstman A, Willemsen V, Boutilier K, Heidstra R (2014) AINTEGUMENTA-LIKE proteins: hubs in a plethora of networks. Trends Plant Sci 19: 146-157

Imin N, Nizamidin M, Wu T, Rolfe BG (2007) Factors involved in root formation in Medicago truncatula. J Exp Bot 58: 439-451

Jofuku KD, den Boer BG, van Montagu M, Okamuro JK (1994) Control of Arabidopsis flower and seed development by the homeotic gene APETALA2. Plant Cell 6: 1211-1225

Karlberg A, Bako L, Bhalerao RP (2011) Short day-mediated cessation of growth requires the downregulation of AINTEGUMENTA LIKE1 transcription factor in hybrid aspen. PLoS Genet 7: e1002361

Kevers C, Hausman JF, Faivre-Rampant O, Evers D, Gaspar $\mathrm{T}$ (1997) Hormonal control of adventitious rooting: Progress and questions. J Appl Bot 71: 71-79

Krizek BA, Prost V, Macias A (2000) AINTEGUMENTA promotes petal identity and acts as a negative regulator of AGAMOUS. Plant Cell 12: 1357-1366

Leple JC, Brasileiro ACM, Michel MF, Delmotte F, Jouanin L (1992) Transgenic poplars: expression of chimeric genes using four different constructs. Plant Cell Rep 11: 137-141

Lovel PH, White J (1986) Anatomical changes during adventitious root formation. In: Jackson MB (ed) New Root Formation in Plants and Cuttings. Martinus Nijhoff Publishers, Dordrecht, The Netherlands, pp 111-140

Mittler R, Vanderauwera S, Suzuki N, Miller G, Tognetti VB, Vandepoele K, Gollery M, Shulaev V, Van Breusegem $F$ (2011) ROS signaling: the new wave? Trends Plant Sci 16: 300-309

Mizukami Y, Fischer RL (2000) Plant organ size control: AINTEGUMENTA regulates growth and cell numbers during organogenesis. Proc Natl Acad Sci USA 97: 942-947

Mochida K, Yoshida T, Sakurai T, Yamaguchi-Shinozaki K, Shinozaki K, Tran LS (2013) TreeTFDB: An Integrative Database of the Transcription Factors from Six Economically Important Tree Crops for Functional Predictions and Comparative and Functional Genomics. DNA Res 20: 151-162

Moubayidin L, Mambro RD, Sabatini S (2009) Cytokinin-auxin crosstalk. Trends Plant Sci 14: 557-562

Negishi N, Oishi M, Kawaoka A (2011) Chemical screening for promotion of adventitious root formation in Eucalyptus globulus. BMC Proc 5(suppl. 7): P139. DOI: 10.1186/1753-6561-5-S7-P139

Nole-Wilson S, Tranby TL, Krizek BA (2005) AINTEGUMENTA-like (AIL) genes are expressed in young tissues and may specify meristematic or division-competent states. Plant Mol Biol 57: 613-628

Peer WA, Murphy AS (2007) Flavonoids and auxin transport: modulators or regulators? Trends Plant Sci 12: 556-563 
Quesada T, Li Z, Dervinis C, Li Y, Bocock PN, Tuskan GA, Casella G, Davis JM, Kirst M (2008) Comparative analysis of the transcriptomes of Populus trichocarpa and Arabidopsis thaliana suggests extensive evolution of gene expression regulation in angiosperms. New Phytol 180: 408-420

Ramírez-Carvajal GA, Morse AM, Dervinis C, Davis JM (2009) The cytokinin type-B response regulator PtRR13 is a negative regulator of adventitious root development in Populus. Plant Physiol 150: 759-771

Raya-González J, Pelagio-Flores R, López-Bucio J (2012) The jasmonate receptor COI1 plays a role in jasmonate-induced lateral root formation and lateral root positioning in Arabidopsis thaliana. J Plant Physiol 169: $1348-1358$

Reichman JL, Meyerowitz EM (1998) The AP2/EREBP family of plant transcription factors. Biol Chem 379: 633-646

Rigal A, Yordanov YS, Perrone I, Karlberg A, Tisserant E, Bellini C, Busov VB, Martin F, Kohler A, Bhalerao R, Legué V (2012) The AINTEGUMENTA LIKE1 homeotic transcription factor PtAIL1 controls the formation of adventitious root primordia in poplar. Plant Physiol 160: 1996-2006

Sanchez C, Vielba JM, Ferro E, Covelo G, Sole A, Abarca D, de Mier BS, Diaz-Sala C (2007) Two SCARECROW-LIKE genes are induced in response to exogenous auxin in rooting-competent cuttings of distantly related forest species. Tree Physiol 27: 1459-1470

Schrader J, Nilsson J, Mellerowicz E, Berglund A, Nilsson P, Hertzberg M, Sandberg G (2004) A high-resolution transcript profile across the wood-forming meristem of poplar identifies potential regulators of cambial stem cell identity. Plant Cell 16: 2278-2292

Schwambach J, Ruedell CM, De Almeida MR, Penchel RM, Araújo EF, Fett-Neto AG (2008) Adventitious rooting of Eucalyptus globulus $\times$ maidennii mini-cuttings derived from mini-stumps grown in sand bed and intermittent flooding trays: a comparative study. New For 36: $261-271$

Smith DL, Fedoroff NV (1995) LRP7, a gene expressed in lateral and adventitious root primordia of Arabidopsis. Plant Cell 7: 735-745

Solé A, Sánchez C, Vielba JM, Valladares S, Abarca D, Díaz-Sala C (2008) Characterization and expression of a Pinus radiata putative ortholog to the Arabidopsis SHORT-ROOT gene. Tree Physiol 28: 1629-1639

Sun J, Chen Q, Qi L, Jiang H, Li S, Xu Y, Liu F, Zhou W, Pan J, Li X, Palme K, Chuanyou L (2011) Jasmonate modulates endocytosis and plasma membrane accumulation of the Arabidopsis PIN2 protein. New Phytol 191: 360-375

Edited by Y. Helariutta
Trupiano D, Yordanov Y, Regan S, Meilan R, Tschaplinski T, Scippa GS, Busov V (2013) Identification, characterization of an AP2/ERF transcription factor that promotes adventitious, lateral root formation in Populus. Planta 238: 271-282

Tuskan GA, DiFazio S, Jansson S, Bohlmann J, Grigoriev I, Hellsten U, Putnam N, Ralph S, Rombauts S, Salamov A, Schein J, Sterck L, Aerts A, Bhalerao RR, Bhalerao RP, Blaudez D, Boerjan W, Brun A, Brunner A, Busov V, Campbell M, Carlson J, Chalot M, Chapman J, Chen G-L, Cooper D, Coutinho PM, Couturier J, Covert S, Cronk Q, Cunningham R, Davis J, Degroeve S, Dejardin A, dePamphilis C, Detter J, Dirks B, Dubchak I, Duplessis S, Ehlting J, Ellis B, Gendler K, Goodstein D, Gribskov M, Grimwood J, Groover A, Gunter L, Hamberger B, Heinze B, Helariutta Y, Henrissat B, Holligan D, Holt R, Huang W, Islam-Faridi N, Jones $S$, Jones-Rhoades $M$, Jorgensen $R$, Joshi $C$, Kangasjarvi J, Karlsson J, Kelleher C, Kirkpatrick R, Kirst M, Kohler A, Kalluri U, Larimer F, Leebens-Mack J, Leple J-C, Locascio P, Lou Y, Lucas S, Martin F, Montanini B, Napoli C, Nelson DR, Nelson C, Nieminen K, Nilsson O, Pereda V, Peter G, Philippe R, Pilate G, Poliakov A, Razumovskaya J, Richardson P, Rinaldi C, Ritland K, Rouzé P, Ryaboy D, Schmutz J, Schrader J, Segerman B, Shin H, Siddiqui A, Sterky F, Terry A, Tsai C-J,

Uberbacher E, Unneberg P, Vahala J, Wall K, Wessler S, Yang G, Yin T, Douglas C, Marra M, Sandberg G, Van de Peer Y, Rokhsar D (2006) The genome of western black cottonwood, Populus trichocarpa (Torr. \& Gray ex Brayshaw). Science 313: 1596-1603

Vielba JM, Díaz-Sala C, Ferro E, Rico S, Lamprecht M, Abarca D, Ballester A, Sánchez C (2011) CsSCL1 is differentially regulated upon maturation in chestnut microshoots, and is specifically expressed in rooting-competent cells. Tree Physiol 31: 1152-1160

Wang J, Andersson-Gunneras Gl, Hertzberg M, Tucker MR, Zheng B, Lesniewska J, Mellerowicz EJ, Laux T, Sandberg G, Jones B (2011) Reduced expression of the SHORT-ROOT gene increases the rates of growth and development in hybrid poplar and Arabidopsis. PLoS One 6: e28878

Wildwater M, Campilho A, Perez- Perez JM, Heidstra R, Blilou I, Korthout H, Chatterjee J, Mariconti L, Gruissem W, Scheres B (2005) The RETINOBLASTOMA-RELATED gene regulates stem cell maintenance in Arabidopsis roots. Cell 123: 1337-1349

Yang X, Kalluri UC, DiFazio SP, Wullschleger SD, Tschaplinski TJ, Cheng ZM, Tuskan GA (2009) Poplar genomics: state of the science. Crit Rev Plant Sci 28: 285-308 